\title{
In Situ Study of High Voltage Performance of Li3Fe2(PO4)3 Cathodes for Li Ion
} batteries

Christiansen, Ane Sælland; Johnsen, Rune; Norby, Poul; Jensen, Søren Højgaard; Frandsen, Cathrine; Mørup, Steen; Kammer Hansen, Kent; Holtappels, Peter

\section{Published in:}

Electrochemical Society. Meeting Abstracts (Online)

Publication date:

2013

Link back to DTU Orbit

Citation $(A P A)$ :

Christiansen, A. S., Johnsen, R., Norby, P., Jensen, S. H., Frandsen, C., Mørup, S., Kammer Hansen, K., \& Holtappels, $\mathrm{P}$. (2013). In Situ Study of High Voltage Performance of $\mathrm{Li}_{3} \mathrm{Fe}_{2}\left(\mathrm{PO}_{4}\right)_{3}$ Cathodes for Li lon batteries. Electrochemical Society. Meeting Abstracts (Online), MA2013-02, 842-842

\section{General rights}

Copyright and moral rights for the publications made accessible in the public portal are retained by the authors and/or other copyright owners and it is a condition of accessing publications that users recognise and abide by the legal requirements associated with these rights.

- Users may download and print one copy of any publication from the public portal for the purpose of private study or research.

- You may not further distribute the material or use it for any profit-making activity or commercial gain

- You may freely distribute the URL identifying the publication in the public portal 


\section{In situ study of high voltage performance of} $\mathrm{Li}_{3} \mathrm{Fe}_{2}\left(\mathrm{PO}_{4}\right)_{3}$ cathodes for $\mathrm{Li}$ ion batteries

Ane S. Christiansen $^{1}$, Rune E. Johnsen ${ }^{1}$, Poul Norby ${ }^{1}$, Søren H. Jensen ${ }^{1}$, Cathrine Frandsen ${ }^{2}$, Steen Mørup ${ }^{2}$, Kent K. Hansen ${ }^{1}$, Peter Holtappels ${ }^{1}$

${ }^{1}$ : Department of Energy Conversion and Storage, Technical University of Denmark, Frederiksborgvej 399, 4000 Roskilde, Denmark, ${ }^{2}$ : Department of Physics, Technical University of Denmark

In order to meet the increasing demands on energy storage capacities in $\mathrm{Li}$ ion batteries, new cathode materials with increased energy density must be developed. One way of achieving this is to use cathodes with multivalent transition metals, which can accommodate more than one $\mathrm{Li}$ ion per metal ion. Iron based compounds constitute a very attractive class of cathode materials as they are cheap, environmentally benign, and potentially a candidate for multivalent electrodes, as iron can exist in several different oxidation states. Despite a large interest, cathodes involving $\mathrm{Fe}^{4+}$ is a great challenge as $\mathrm{Fe}^{4+}$ is unstable in most solid state structures. This instability is observed in layered $\mathrm{LiFeO}_{2}$, which irreversibly converts into a spinel-type $\mathrm{LiFe}_{5} \mathrm{O}_{8}$ structure after cycling ${ }^{(1)}$. Recently, $\mathrm{Li}_{2} \mathrm{FeSiO}_{4}$ is starting to get attention as a possible new $\mathrm{Fe}^{4+}$-based cathode ${ }^{(2)}$, although the reversibility of this process is still to be determined.

In this study, we investigate whether $\mathrm{Fe}^{4+}$ can be formed and stabilized in rhombohedral $\beta-\mathrm{Li}_{3} \mathrm{Fe}_{2}\left(\mathrm{PO}_{4}\right)_{3}$, which is based on the highly stable NASICON framework ${ }^{(3)}$. Intercalation of $\mathrm{Li}$ ions into the structure involving the $\mathrm{Fe}^{2+} / \mathrm{Fe}^{3+}$ transition is well known ${ }^{(4,5)}$, but this work is focused on the possible extraction of $\mathrm{Li}$ ions involving the $\mathrm{Fe}^{3+} / \mathrm{Fe}^{4+}$ transition. The work is based on an in situ synchrotron X-ray powder diffraction (XRPD) study of the structural changes, that occur during charging of $\beta$ $\mathrm{Li}_{3} \mathrm{Fe}_{2}\left(\mathrm{PO}_{4}\right)_{3}$ up to $5.2 \mathrm{~V}$ vs. $\mathrm{Li} / \mathrm{Li}^{+}$. A novel capillarybased micro battery cell for in situ XRPD has been designed for this (figure 1). The advantage of this cell is that it allows diffractions from the individual electrode layers, and also facilitates time-resolved studies of chemical gradients within the electrode layers.

A small contraction in volume was observed during charge to $5.2 \mathrm{~V}$, indicating $\mathrm{Li}$ ion extraction (figure 2). The volume change is anisotropic, with a decrease in the $a$ parameter and an increase in the $c$ parameter during the extraction of $0.2 \mathrm{Li}$ ions per $\mathrm{Li}_{3} \mathrm{Fe}_{2}\left(\mathrm{PO}_{4}\right)_{3}$. The charging is performed at potentials above the stability window of the organic electrolyte and some electrolyte oxidation reaction cannot be avoided. However, the observed volume changes show that $\mathrm{Li}^{+}$extraction has occurred probably associated with $\mathrm{Fe}^{4+}$ formation. The change of oxidation state of iron was investigated by Mössbauer spectroscopy using an in situ setup in order to fully subtract all background absorption, however no evidence of $\mathrm{Fe}^{4+}$ formation was observed. Instability of the $\mathrm{Fe}^{4+}$ towards the organic electrolyte could possibly explain this. $\mathrm{Li}^{+}$extraction occurs at a plateau above $4.5 \mathrm{~V}$ but no discharge plateau above $3 \mathrm{~V}$ was observed. This is also the case for intercalation into $\mathrm{FeSiO}_{4}{ }^{(2)}$. This indicates that the intercalation of $\mathrm{Li}$ ions into these materials is not followed by a simple $\mathrm{Fe}^{4+} / \mathrm{Fe}^{3+}$ reduction. Future work will be addressed to understand this lack of plateau.

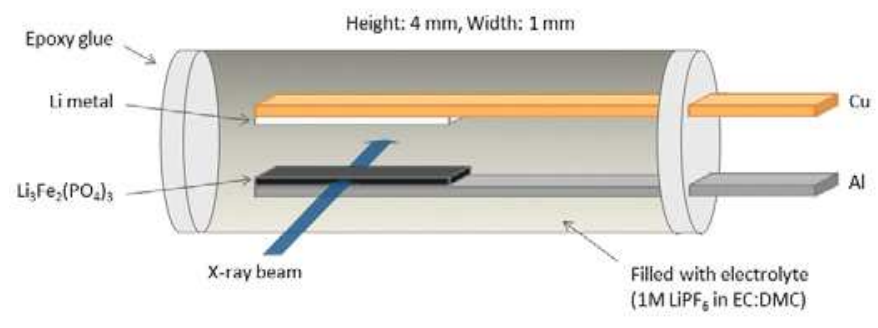

Figure 1: Illustration of a new capillary-based micro battery cell for in situ synchrotron XRPD.

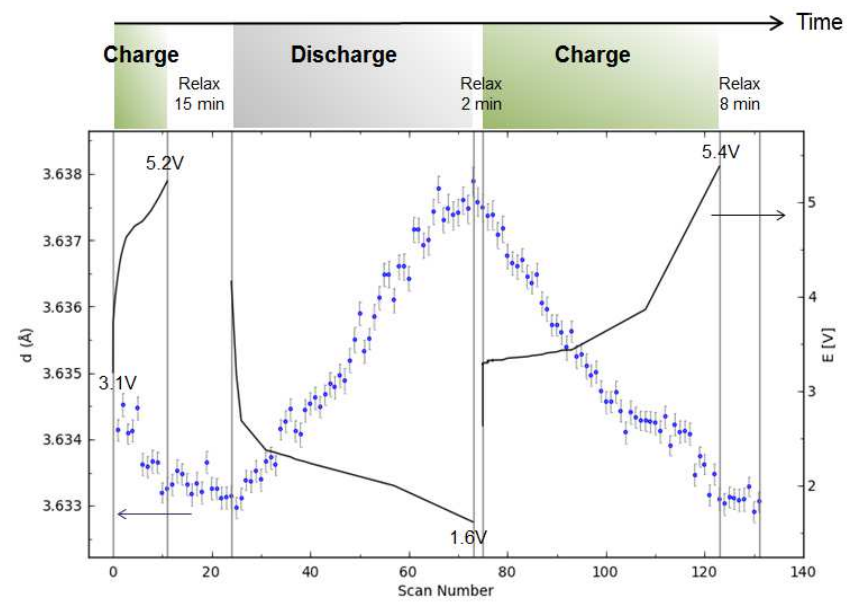

Figure 2: Change in $d$-spacing of the (113) planes in $\mathrm{Li}_{3} \mathrm{Fe}_{2}\left(\mathrm{PO}_{4}\right)_{3}$ measured by in situ synchrotron XRPD. Charging the cell results in contraction of the structure while discharge results in expansion, associated with the extraction and intercalation of $\mathrm{Li}$ ions.

\section{References}

1. Armstrong, A. R., Tee, D. W., La Mantia, F., Novák, P. and Bruce, P. G. J.Am.Chem.Soc., 130, 3554 (2008).

2. Rangappa, D., Murukanahally, K. D., Tomai, T., Unemoto, A. and Honma, I. Nano letters, 12, 1146 (2012).

3. Masquelier, C., Wurm, C., Rodriguez-Carvajal, J., Gaubicher, J. and Nazar, L. Chem. Mater., 12, 525 (2000).

4. Masquelier, C., Padhi, A. K., Nanjundaswamy, K. S., Goodenough, J. B. J. Solid State Chem., 135, 228 (1998).

5. Andersson, A.S., Kalska, B., Eyob, P., Aernout, D., Häggström, L. and Thomas, J.O., Solid State Ionics 140, 63-70 (2001). 